\title{
Harnessing Production Potential of Acidic Soils: Impacts of Azolla (Azolla pinnata) Bio-fertilizer and Urea on Rice (Oryza sativa L.) Performance, Temporal Soil P Availability and Acidity Indices
}

\author{
*Corresponding Author \\ Sanjay-Swami

\section{Article History} \\ Received: 22.06.2019 \\ Accepted: 16.07 .2019 \\ Published: 30.07 .2019
}

Sanjay-Swami* and Shubham Singh

School of Natural Resource Management, College of Post Graduate Studies in Agricultural Sciences, Central Agricultural University, Umiam-793103, Meghalaya

\begin{abstract}
A field experiment was conducted during kharif 2017-18 to investigate the impacts of azolla (Azolla pinnata) biofertilizer and urea on rice (Oryza sativa L.) yield, temporal soil $P$ availability and improvement in soil acidity indices under low land acidic soil of Meghalaya. Six treatments viz., control ( $\left.T_{1}\right)$, fresh azolla incorporation @ $16000 \mathrm{~kg} \mathrm{ha}^{-1}\left(\mathrm{~T}_{2}\right), 30 \mathrm{~kg} \mathrm{~N}$ ha-1 through urea $\left(T_{3}\right), 60 \mathrm{~kg} \mathrm{~N} \mathrm{ha}^{-1}$ through urea $\left(\mathrm{T}_{4}\right), 30 \mathrm{~kg} \mathrm{~N} \mathrm{ha}^{-1}$ through urea + azolla incorporation @ $16000 \mathrm{~kg} \mathrm{ha}^{-1}\left(\mathrm{~T}_{5}\right)$ and $60 \mathrm{~kg} \mathrm{~N} \mathrm{ha}^{-1}$ through urea with azolla incorporation @ $16000 \mathrm{~kg} \mathrm{ha}^{-1}\left(\mathrm{~T}_{6}\right)$ were tested in Randomized Block Design with four replications. Application of 60 $\mathrm{kg} \mathrm{N} \mathrm{ha}^{-1}$ through urea along with azolla incorporation @ $16000 \mathrm{~kg} \mathrm{ha}^{-1}\left(\mathrm{~T}_{6}\right)$ produced highest grain yield $\left(4.2 \mathrm{t}\right.$ ha-1) followed by $T_{5}$ and $\mathrm{T}_{4}$. It had significantly greater available phosphorus at 30 DAT $\left(24.13 \mathrm{P}_{2} \mathrm{O}_{5} \mathrm{~kg} \mathrm{ha}^{-1}\right)$ and at maturity $\left(20.63 \mathrm{P}_{2} \mathrm{O}_{5} \mathrm{~kg} \mathrm{ha}^{-1}\right)$ followed by 30 $\mathrm{kg} \mathrm{N} \mathrm{ha-1}$ through urea + azolla incorporation @ $16000 \mathrm{~kg} \mathrm{ha}^{-1}\left(\mathrm{~T}_{5}\right)$, compared to control and other treatment plots. Available phosphorus in $T_{6}$ was statistically significant over $T_{4}\left(60 \mathrm{~kg} \mathrm{~N}^{-1}\right.$ through urea) whereas $T_{5}$ was significant over $T_{3}\left(30 \mathrm{~kg} \mathrm{~N}^{-1}\right.$ through urea) with respect to advancement in crop age. The soil acidity indices reflected highest improvement with azolla bio-fertilizer incorporation @ $16000 \mathrm{~kg} \mathrm{ha}^{-1}\left(\mathrm{~T}_{2}\right)$ over all other treatments indicating that azolla bio-fertilizer can be an alternative option for acid soil management.
\end{abstract}

Keywords: Soil acidity, azolla incorporation, rice yield, temporal soil $\mathrm{P}$, soil acidity indices

\section{INTRODUCTION}

Soil acidity is one of the major constraints in crop production throughout the world. Globally, it affects about 3.95 billion ha land area [1] which is about 30 per cent of the world's ice-free land area. About 40.9 per cent of America, 26.4 per cent of Asia, 16.7 per cent of Africa, 9.9 per cent of Europe, and 6.1 per cent of Australia and New Zealand have acid soils [2]. These soils cover a significant part of at least 48 developing countries, especially located in the tropical areas [3]

In India, approximately one-third of the cultivated land is affected by soil acidity [4]. These soils are distributed in the Himalayan region, the eastern and the north-eastern plains, peninsular India and the coastal plains under varying agro-climatic conditions. Majority of these soils are concentrated in North-Eastern Region (NER) of India where approximately 95 per cent soils are acidic, with nearly 65 per cent soils under strong acidity with $\mathrm{pH}$ less than 5.5 [5].

Soil acidity influences many chemical and biological reactions that control plant nutrient availability and the toxicity of some elements [6]. Crop productivity on such soils is mostly constrained by aluminium (Al) and iron (Fe) toxicity, phosphorus (P) deficiency, low base saturation, impaired biological activity and other acidity-induced soil fertility and plant nutritional problems $[7,8]$. The levels of soil acidity along with its associated impacts on soil fertility and crop productivity are expected to further intensify in a changing climate [9]. Soil acidity management and crop productivity improvement on such soils is therefore important for enhancing food security globally and regionally.

Copyright @ 2019: This is an open-access article distributed under the terms of the Creative Commons Attribution license which permits unrestricted use, distribution, and reproduction in any medium for non commercial use (NonCommercial, or CC-BY-NC) provided the original author and source are credited. 
Meghalaya is an agriculturally important state in NER of India, with typically high levels of soil acidity and very high rainfall. Acidity-induced soil fertility problems coupled with traditionally minimal use of mineral fertilizers are often held responsible for low levels of crop productivity in the state. Phosphorus deficiency occurs widely in lowland soils that possess high native P-fixing capacity, especially in acidic soil. The toxicity of soil aluminium has been recognized as one of the important factors limiting the productivity of rice on acid soils with $\mathrm{pH}$ less than 5.5. As a result, the productivity of the acid soils of Meghalaya is very low $\left(<1 \mathrm{t} \mathrm{ha} \mathrm{a}^{-1}\right)$. There are several indices used to correct soil acidity for maximizing crop yields. These indices include $\mathrm{pH}$, base saturation, acidity saturation, aluminum saturation, calcium saturation, magnesium saturation, potassium saturation, $\mathrm{Ca} / \mathrm{Mg}$ ratio, $\mathrm{Ca} / \mathrm{K}$ ratio, and $\mathrm{Mg} / \mathrm{K}$ ratio (Fageria, 2008) [10]. Quantifying optimum soil acidity indices is an important strategy for achieving maximum economic rice yield on acid soils.

Phosphorus deficiency coupled with low P-fertilizer use efficiency (P-fue), more often only 10-15 per cent has been observed to be a limiting factor for rice production in low land acidic soils. It is defined as yield increase per kg fertilizer $\mathrm{P}$ added, is related to $\mathrm{P}$ sources, environmental factors, soil, and crop management practices. To maintain an adequate supply of plant available $P$, the conventional practices of liming and regular application of $P$ fertilizers are carried out. Over liming can cause $P$ fixation by calcium, and excessive or unbalanced use of $\mathrm{P}$ fertilizers may result in eutrophication. Moreover, liming may also not be economical in regions where it is expensive.

Although, some information on $P$ sorption and fixation using organic matter incorporation in acid soils exist [11, 12], there is dearth of information on the use of azolla (Azolla pinnata) to minimize P fixation in acid soils. Azolla is a floating fern having endosymbiotic $\mathrm{N}_{2}$ fixing Cyanobacterium, Anabaena azollae. It is a multipurpose crop and can be used as bio-fertilizer also. The average $\mathrm{N}, \mathrm{P}$ and $\mathrm{K}$ content in azolla on dry weight basis are 4.0-7.0, 0.6-0.8 and 2.0-4.0 per cent, respectively. With a doubling of biomass within two days, azolla ranks amongst the fastest-growing plants on our planet and thus can provide large bio-mass. The efficient use of azolla is still limited due to lack of insights in the $\mathrm{P}$ availability with time and in the corresponding mechanisms. The aim of this work was to evaluate the performance of azolla (Azolla pinnata) integrated with urea on rice (Oryza sativa L.) cv. Shasharang in low land acidic soil, temporal soil phosphorus availability and soil acidity indices.

\section{MATERIALS AND METHODS}

The experiment was conducted at Research Farm of the College of Post-Graduate Studies in Agricultural Sciences (CPGSAS), Central Agricultural University, Umiam, Ri-Bhoi district of Meghalaya located at 91018' to 92018' E longitude and 25040' to 26020' $\mathrm{N}$ latitude with an altitude of $950 \mathrm{~m}$ above the mean sea level. The experimental soil was having $\mathrm{pH} 5.1, \mathrm{SOC} 1.75$ per cent, available

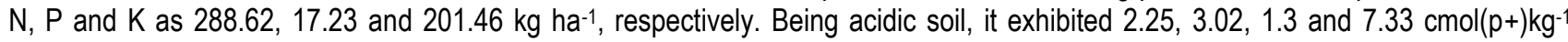
exchangeable aluminium, exchangeable acidity, exchangeable calcium ( $\mathrm{Ca})+$ magnesium $(\mathrm{Mg})$, and cation exchange capacity (CEC), respectively. The field experiment was conducted during kharif season of 2017 taking rice as test crop in Randomized Block Design (RBD) having six treatments and four replications viz., control ( $\left.T_{1}\right)$, azolla incorporation @ $16000 \mathrm{~kg} \mathrm{ha}^{-1}$ on fresh weight basis $\left(\mathrm{T}_{2}\right), 30$ $\mathrm{kg} \mathrm{N} \mathrm{ha}^{-1}$ through urea $\left(\mathrm{T}_{3}\right), 60 \mathrm{~kg} \mathrm{~N} \mathrm{ha}^{-1}$ through urea $\left(\mathrm{T}_{4}\right), 30 \mathrm{~kg} \mathrm{~N} \mathrm{ha}^{-1}$ through urea + azolla incorporation @ $16000 \mathrm{~kg} \mathrm{ha} \mathrm{k}^{-1}\left(\mathrm{~T}_{5}\right)$ and $60 \mathrm{~kg} \mathrm{~N} \mathrm{ha}^{-1}$ through urea with azolla incorporation @ $16000 \mathrm{~kg} \mathrm{ha}^{-1}\left(\mathrm{~T}_{6}\right)$. All the agronomic practices were followed for raising test crop. The N, $\mathrm{P}$ and $\mathrm{K}$ content in azolla on dry weight basis was $4.2,0.6$ and 1.9 per cent, respectively.

Grain and biological yield of rice were recorded after the harvest of the crop when optimum moisture content was achieved and expressed in tha-1. The soil samples from each plot were collected by core sampling at 30,60,90 days after transplanting and at maturity of rice crop. Soils were mixed, dried, ground and passed through a $0.2 \mathrm{~mm}$ stainless sieve and available phosphorus was estimated by stannous chloride blue colour method $[13,14]$. Soil acidity indices were estimated using standard methods and calculated with the help of the following formulas:

$$
\operatorname{CEC}\left(\mathrm{cmol}_{\mathrm{c}} \mathrm{kg}^{-1}\right)=\sum\left(\mathrm{Ca}^{2+}, \mathrm{Mg}^{2+}, \mathrm{K}^{+}, \mathrm{H}^{+}, \mathrm{Al}^{3+}\right)
$$

Where $\mathrm{Ca}, \mathrm{Mg}, \mathrm{K}, \mathrm{H}$ and $\mathrm{Al}$ are in centimoles of positive charge per kilogram.

$$
\begin{gathered}
\text { Base saturation }(\%)=\frac{\sum(\mathrm{Ca}, \mathrm{Mg}, \mathrm{K}, \mathrm{Na})}{\mathrm{CEC}} \times 100 \\
\text { Aliminum saturation }(\%)=\frac{(\mathrm{Al})}{\sum(\mathrm{Ca}, \mathrm{Mg}, \mathrm{K}, \mathrm{Al})} \times 100 \\
\text { Acidity saturation }(\%)=\frac{(\mathrm{H}+\mathrm{Al})}{\mathrm{CEC}} \times 100 \\
\text { Saturation of } \mathrm{Ca}, \mathrm{Mg} \text { and } \mathrm{K}(\%)=\frac{(\mathrm{Ca})}{\mathrm{CEC}} \times 100, \frac{(\mathrm{Mg})}{\mathrm{CEC}} \times 100 \text { or } \frac{(\mathrm{K})}{\mathrm{CEC}} \times 100
\end{gathered}
$$




$$
\text { Ratios of Ca: } \mathrm{Mg} \text {, Ca: } \mathrm{K} \text { and } \mathrm{Mg}: \mathrm{K}=\frac{\mathrm{Ca}}{\mathrm{Mg}}, \frac{\mathrm{Ca}}{\mathrm{K}} \text { or } \frac{\mathrm{Mg}}{\mathrm{K}}
$$

The data recorded for various parameters were analyzed statistically by following procedure of Gomez and Gomez [15].

\section{RESULTS AND DISCUSSION \\ Grain and biological yield ( $\left.\mathrm{t} \mathrm{ha}^{-1}\right)$}

Grain yield of rice increased significantly with different levels of azolla bio-fertilizer and urea (Fig. 1). Grain yield varied from 2.73 to $4.2 \mathrm{t} \mathrm{ha}^{-1}$ amongst different treatment combinations. It was found that T6 $60 \mathrm{~kg} \mathrm{~N} \mathrm{ha}^{-1}$ through urea + azolla incorporation @ $\left.16000 \mathrm{~kg} \mathrm{ha}^{-1}\right)$ gave highest yield with $4.2 \mathrm{t} \mathrm{ha}^{-1}$ which was trailed by $T_{5}$ (30 kg N ha-1 through urea + azolla incorporation @ $16000 \mathrm{~kg}$ $\left.\mathrm{ha}^{-1}\right)$ with $3.77 \mathrm{t} \mathrm{ha}^{-1}$. The per cent increase in $\mathrm{T}_{5}$ over $\mathrm{T}_{3}\left(30 \mathrm{~kg} \mathrm{~N} \mathrm{ga}^{-1}\right.$ through urea) was 17.81 per cent whereas, $\mathrm{T}_{6}$ increased over $\mathrm{T}_{4}$ (60 kg N ha-1 through urea) by 17.65 per cent. There was 53.84 per cent increase in grain yield in $\mathrm{T}_{6}$ over $\mathrm{T}_{1}$. Further, it was observed that the grain yield obtained in $T_{2}$ was statistically at par with $T_{3}$. The values of this parameters obtained in $T_{4}$ were statistically at par with the values obtained in $T_{5}$. Among the sole treatment of azolla and urea, urea treatment showed better performance. Different treatments brought significant difference on biological yield of rice. Highest biological yield was recorded in $\mathrm{T}_{6}\left(60 \mathrm{~kg} \mathrm{~N}^{-1} \mathrm{through}^{-}\right.$ urea + azolla incorporation @ $16000 \mathrm{~kg} \mathrm{ha}^{-1}$ ) which was significantly superior over T1 (control), T2 (azolla incorporation @ $16000 \mathrm{~kg}$ $\mathrm{ha}^{-1}$ ) and $\mathrm{T}_{3}$ (30 kg N ha-1 through urea) whereas statistically at par with $\mathrm{T}_{4}\left(60 \mathrm{~kg} \mathrm{~N}^{-1}\right.$ through urea) and $\mathrm{T}_{5}$ (30 kg N ha-1 through urea + azolla incorporation @ $\left.16000 \mathrm{~kg} \mathrm{ha}^{-1}\right)$.

These results confirmed the findings of many earlier researchers. Buragohain et al. [16] reported that the incorporation of fresh or dry azolla biomass into the soil always increased grain and straw yield of rice. They also reported that azolla hybrid along with fertilizer nitrogen increased the grain yield and yield component of rice. The results obtained by Mensah et al. [17] also corroborate with this fact. Similarly, Chandel et al. [18] obtained significant increase in grain yield of rice when azolla was used along with $100 \mathrm{~kg} \mathrm{~N}$ $\mathrm{ha}^{-1}$ as USG (Urea Super Granule). The reason for increased yield components and grain yield of rice in azolla incorporated treatments might be due to higher availability of azolla nitrogen to rice plants. When azolla is incorporated into the flooded soil, it undergoes active decomposition and the nitrogen released in ammonical form is readily absorbed by the rice plants. The low yield reported in azolla unincorporated treatments could be due to non-availability of additional azolla-N to rice plants. Ghosh et al. [19] also reported that rice plants absorbed more than 50 per cent of $15 \mathrm{~N}$ labelled azolla-N incorporated at the time of transplanting, however when azolla was kept on the surface of water, less than 10 per cent of its $\mathrm{N}$ was available to the rice plants. So the efficiency of azolla bio-fertilizer could be increased by incorporating it into the rice soil, which avoids losses of nitrogen and higher yield response could be obtained from rice plants. Increased dry matter and grain yields as observed in the present study with azolla application also had been reported by Ladha et al. [20].

\section{Temporal soil $P$ availability}

The soil available phosphorus content in all treatments was statistically significant over $T_{1}$ (control) as shown in Fig. 2. The combined application of azolla and urea exhibited a significant effect on available phosphorus in the soil. The $\mathrm{T}_{6}\left(60 \mathrm{~kg} \mathrm{~N} \mathrm{ha}^{-1}\right.$ through urea with azolla incorporation @ $\left.16000 \mathrm{~kg} \mathrm{ha}^{-1}\right)$ treated plot had significantly greater available phosphorus $24.13 \mathrm{P}_{2} \mathrm{O}_{5} \mathrm{~kg} \mathrm{ha}^{-1}$ and $20.63 \mathrm{P}_{2} \mathrm{O}_{5} \mathrm{~kg} \mathrm{ha}^{-1}$ at 30 DAT and in the soil samples collected at maturity, followed by $\mathrm{T}_{5}\left(30 \mathrm{~kg} \mathrm{~N} \mathrm{ha}^{-1}\right.$ through urea + azolla incorporation @ $16000 \mathrm{~kg} \mathrm{ha}^{-1}$ ) treated plots in comparison to control and other treatment plots. The $\mathrm{T}_{5}$ and $\mathrm{T}_{6}$ treatments registered 23.99 and 29.40 per cent higher available phosphorus than the control in the soil samples collected at maturity stage. A perusal of the data revealed that available phosphorus varied from $14.91 \mathrm{P}_{2} \mathrm{O}_{5} \mathrm{~kg} \mathrm{ha}^{-1}$ under control $\left(\mathrm{T}_{1}\right)$ in the soil samples collected at maturity to $24.13 \mathrm{P}_{2} \mathrm{O}_{5} \mathrm{~kg} \mathrm{ha}^{-1}$ under $\mathrm{T}_{6}$ at 30 DAT. Further, it was also observed that available phosphorus in $\mathrm{T}_{6}$ was statistically significant over $\mathrm{T}_{4}$ (60 kg N ha-1 through urea) whereas $\mathrm{T}_{5}$ was significant over $\mathrm{T}_{3}\left(30 \mathrm{~kg} \mathrm{~N} \mathrm{ha}^{-1}\right.$ through urea) with respect to advancement in crop age. Also, $\mathrm{T}_{2}$ (azolla incorporation @ $16000 \mathrm{~kg} \mathrm{ha}^{-1}$ ) showed significant increase in available phosphorus over $\mathrm{T}_{1}$. The values of available phosphorus in $T_{1}$ were statistically at par with $T_{4}$ and $T_{3}$ respectively with respect to days after transplanting (DAT). When treatment $T_{2}$ was compared with $T_{4}$ and $T_{3}$, it was observed that there was a significant increase with respect to advancement in crop age.

The higher soil available phosphorus in combined treatments might be due to higher content of organic carbon and thus help converting the immobilized phosphorus into labile or inorganic phosphorus. The increase of available phosphorus could also be explained by better soil condition and subsequently lesser phosphorus fixation. Incorporation of azolla in combination with urea recorded higher content of phosphorus in soil may be attributed to higher addition of organic matter which helped in releasing the higher amounts of phosphorus from the soil. Organic manure enhanced the labile $P$ in the soil through complexation of cations like $\mathrm{Ca}^{+2}$ and $\mathrm{Mg}^{+2}$ when it is applied in combination with urea. Generally, addition of organic manures with chemical fertilizers had the beneficial effect in increasing the phosphate availability [21-23].

\section{Soil acidity indices \\ Soil reaction}

A slight increase in soil pH was observed in the treatments where azolla is used whereas soil pH slightly decreased where urea is used in comparison to the initial soil pH (5.1) recorded at the time of initiation of the experiment (Fig. 3). The pH of the soil 
ranged from 4.96 to 5.35. The highest $\mathrm{pH}$ value (5.35) was recorded in $\mathrm{T}_{2}$ (azolla incorporation @ $16000 \mathrm{~kg}^{-1}$ ) whereas the lowest value (4.96) was recorded in $\mathrm{T}_{4}\left(60 \mathrm{~kg} \mathrm{~N} \mathrm{Na}^{-1}\right.$ through urea). The increase in soil $\mathrm{pH}$ might be attributed to decrease of $\mathrm{Al}^{3^{+}}$and release of basic cations during decomposition of organic manures, whereas application of nitrogenous fertilizers decreases the $\mathrm{pH}$ due to residual acidity of fertilizers. These results are in consonance with the findings of Zhang et al. and Yaduvanshi and Sharma [24, 25].

\section{Exchangeable aluminium and exchangeable acidity}

Exchangeable aluminium in soil significantly varied among the treatments (Fig. 3). The exchangeable Al in soil ranged from 1.92 to $2.37 \mathrm{cmol}(\mathrm{p}+) \mathrm{kg}^{-1}$. The highest value $\left(2.37 \mathrm{cmol}\left(\mathrm{p}^{+}\right) \mathrm{kg}^{-1}\right)$ was recorded in $\mathrm{T}_{4}\left(60 \mathrm{~kg} \mathrm{~N} \mathrm{ha}^{-1}\right.$ through urea) whereas the lowest value $\left(1.92 \mathrm{cmol}\left(\mathrm{p}^{+}\right) \mathrm{kg}^{-1}\right.$ ) was recorded in $\mathrm{T}_{2}$ (azolla incorporation @ $16000 \mathrm{~kg} \mathrm{ha}{ }^{-1}$ ). A slight increase in exchangeable Al was observed in the treatments where urea is used, whereas a slight decrease was observed where azolla is used in comparison to the initial exchangeable $\mathrm{Al}\left(2.25 \mathrm{cmol}\left(\mathrm{p}^{+}\right) \mathrm{kg}^{-1}\right)$ recorded at the time of initiation of the experiment. There was an increase of 18.99 percent in $60 \mathrm{~kg} \mathrm{~N} \mathrm{ha}^{-1}$ through urea over azolla incorporation @ $16000 \mathrm{~kg} \mathrm{ha}^{-1}$.

The exchangeable acidity content in all treatments was non-significant as presented in Fig. 3. The exchangeable acidity in soil ranged from 2.77 to $3.10 \mathrm{cmol}(\mathrm{p}+) \mathrm{kg}^{-1}$. The highest value $\left(3.10 \mathrm{cmol}(\mathrm{p}+) \mathrm{kg}^{-1}\right)$ was recorded in $\mathrm{T}_{4}\left(60 \mathrm{~kg} \mathrm{~N}^{-1}\right.$ through urea) whereas the lowest value $\left(2.77 \mathrm{cmol}\left(\mathrm{p}^{+}\right) \mathrm{kg}^{-1}\right)$ was recorded in $\mathrm{T}_{2}$ (azolla incorporation @ $16000 \mathrm{~kg} \mathrm{ha}^{-1}$ ). This might be attributed to the fact that the proton consuming ability of humic materials might have reduced acidity in this case. The slow reduction of acidity might be explained by the steady formation of organic material with functional groups such as carboxyl and phenolic groups during decomposition and by the low solubility of $\mathrm{CaCO}_{3}$. Moreover, the $\mathrm{pH}$ increase with azolla bio-fertilizer treatment could be attributed to the reduction of exchangeable aluminium and acidity in these acidic soils $(\mathrm{pH} 4.5-5.5)$. This reduction is considered to occur through aluminium and hydrogen precipitation or chelation on organic colloids or by complexation of soluble aluminium and hydrogen by organic molecules, especially organic acids [26].

\section{Exchangeable $\mathrm{Ca}$ and $\mathrm{Mg}$}

The data on exchangeable $\mathrm{Ca}$ and $\mathrm{Mg}$ presented in Fig. 3 shows that there was a non-significant effect by different treatments. The exchangeable $\mathrm{Ca}$ and $\mathrm{Mg}$ of the soil ranged from 1.18 to $1.92 \mathrm{cmol}\left(\mathrm{p}^{+}\right) \mathrm{kg}^{-1}$. The highest value $\left(1.92 \mathrm{cmol}(\mathrm{p}+) \mathrm{kg}^{-1}\right)$ was recorded in $T_{2}$ (azolla incorporation @ $16000 \mathrm{~kg} \mathrm{ha}^{-1}$ ) whereas the lowest value $\left(1.18 \mathrm{cmol}(\mathrm{p}+) \mathrm{kg}^{-1}\right)$ was recorded in $\mathrm{T}_{4}(60 \mathrm{~kg} \mathrm{~N}$ $\mathrm{ha}^{-1}$ through urea). An increase in exchangeable $\mathrm{Ca}$ and $\mathrm{Mg}$ was observed in the treatments where azolla is used whereas slight decrease in exchangeable $\mathrm{Ca}$ and $\mathrm{Mg}$ was recorded where urea is used as compared to the initial $\left(1.3 \mathrm{cmol}\left(\mathrm{p}^{+}\right) \mathrm{kg}^{-1}\right)$ exchangeable

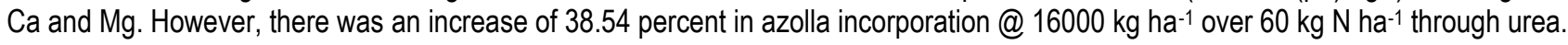

Azolla treatment in both sole and combined was found to be superior in maintaining higher concentration of exchangeable calcium and magnesium over sole application of urea which might be due to higher concentration of organic matter in the soil. The higher concentration of exchangeable calcium and magnesium in azolla treatments over the urea treatments and control was due to the fact that azolla additions increased the exchangeable calcium status of the soils due to increase in biomass production and its incorporation in the soil. Better soil physical conditions increased soil microbiological activity and more mineralization by the microbes from soil pool which might have increased the exchangeable calcium in the soil. Similar observations have been reported by Sharma et al. [27, 28].

\section{Exchangeable CEC}

The exchangeable CEC of the soil was significantly and positively correlated with different treatment combinations (Fig. 3). It ranged from 6.99 to $7.90 \mathrm{cmol}\left(\mathrm{p}^{+}\right) \mathrm{kg}^{-1}$. The highest value $\left(7.90 \mathrm{cmol}\left(\mathrm{p}^{+}\right) \mathrm{kg}^{-1}\right)$ was recorded in $\mathrm{T}_{2}$ (azolla incorporation @ $16000 \mathrm{~kg}$ $\left.\mathrm{ha}^{-1}\right)$ due to higher organic carbon content whereas the lowest value $\left(6.99 \mathrm{cmol}\left(\mathrm{p}^{+}\right) \mathrm{kg}^{-1}\right)$ was recorded in $\mathrm{T}_{4}\left(60 \mathrm{~kg} \mathrm{~N} \mathrm{ha}^{-1}\right.$ through urea). The treatments receiving azolla bio-fertilizer were superior in maintaining exchangeable CEC due to high biomass incorporation in the soil. Similar observations were reported by Chyamweshi et al. [29].

\section{Base saturation percentage}

Base Saturation Percentage (BSP) in T6 (60 kg N ha-1 through urea + azolla incorporation @ $16000 \mathrm{~kg} \mathrm{ha}^{-1}$ ) was significant over $\mathrm{T}_{1}$ as presented in Fig. 4. The base saturation percentage of the soil ranged from 16.88 to 24.3 per cent. The highest value (24.3 per cent) was recorded in $T_{2}$ (azolla incorporation @ $16000 \mathrm{~kg} \mathrm{ha}^{-1}$ ) whereas the lowest value (16.88 per cent) was recorded in $\mathrm{T}_{4}(60$ $\mathrm{kg} \mathrm{N}^{-1}$ through urea). Base saturation is the percentage of the CEC occupied by the basic cations like $\mathrm{Ca}^{+2}, \mathrm{Mg}^{+2}$ and $\mathrm{K}^{+}$. It followed the same trends as exchangeable $\mathrm{Ca}^{+2}$ and $\mathrm{Mg}^{+2}[30,31]$.

\section{Acidity saturation percentage}

Acidity saturation is the percentage of the CEC occupied by the acidic cations like $\mathrm{H}^{+}$and $\mathrm{Al}^{+3}$. Acidity Saturation Percentage (ASP) in soil was significant between the treatments. The acidity saturation percentage in soil ranged from 75.7 to 83.12 per cent. The highest value (83.12 per cent) was recorded in $T_{4}\left(60 \mathrm{~kg} \mathrm{~N} \mathrm{ha}^{-1}\right.$ through urea) whereas the lowest (75.7 per cent) was recorded in $\mathrm{T}_{2}$ (azolla incorporation @ $16000 \mathrm{~kg} \mathrm{ha}^{-1}$ ). It followed the same trends as exchangeable Al and exchangeable acidity [32]. It may be concluded from present study that application of $60 \mathrm{~kg} \mathrm{~N} \mathrm{ha}^{-1}$ through urea in combination with incorporation of azolla 
@ $16000 \mathrm{~kg} \mathrm{ha}^{-1}$ is the best suitable option for getting optimum production of rice and sustainability of soil health in low land acid soil of Meghalaya.

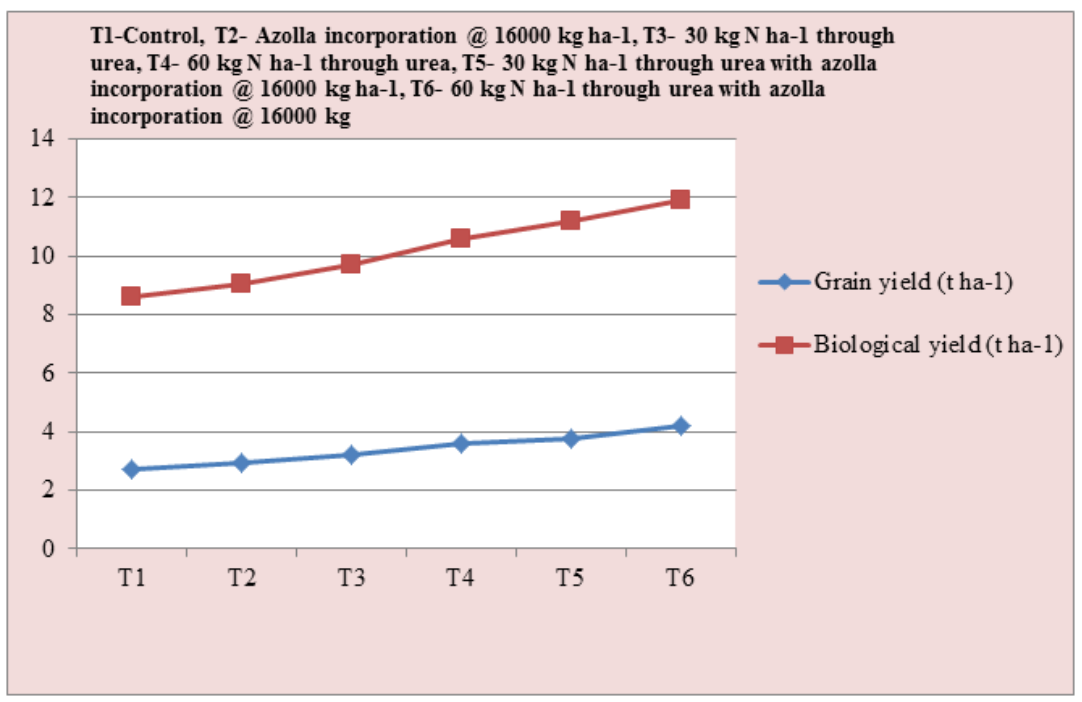

Fig-1: Impact of azolla bio-fertilizer and urea on grain and biological yield Of rice ( $\mathrm{t} \mathrm{ha}^{-1}$ ) in low land acidic soil of Meghalaya

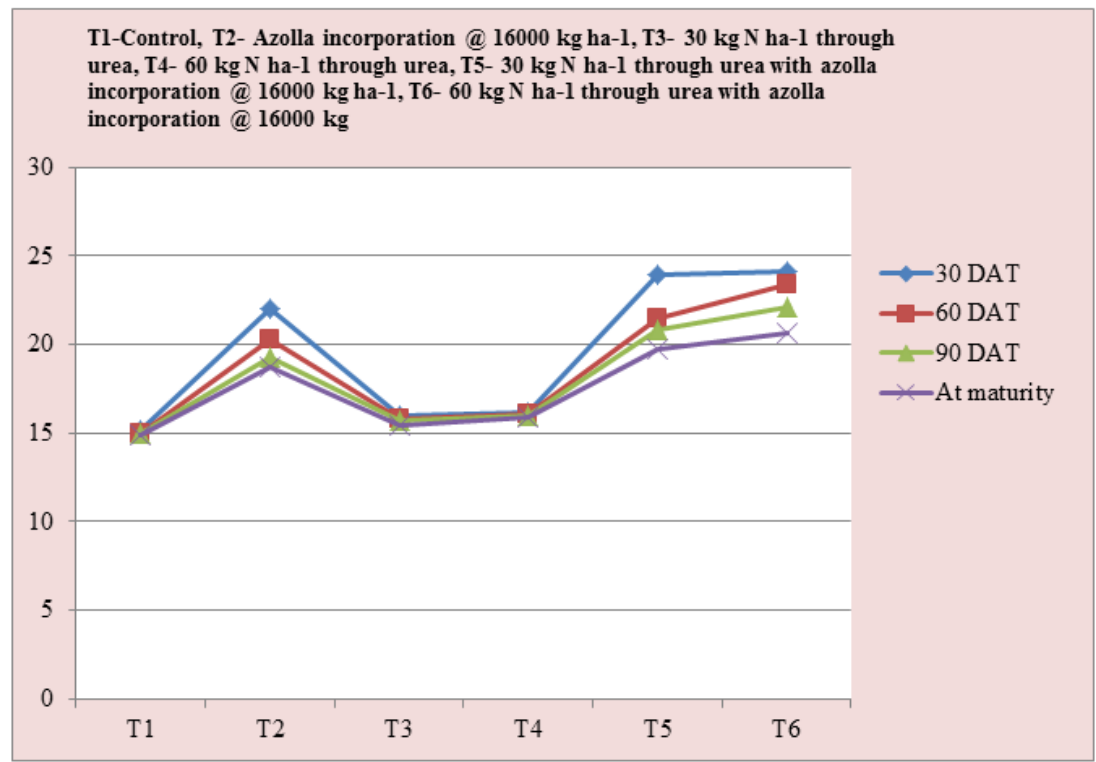

Fig-2: Temporal soil phosphorus availibility (kg ha-1) as afftected by azolla bio-fertilizer and urea during rice cultivation in low land acidic soil of Meghalaya 


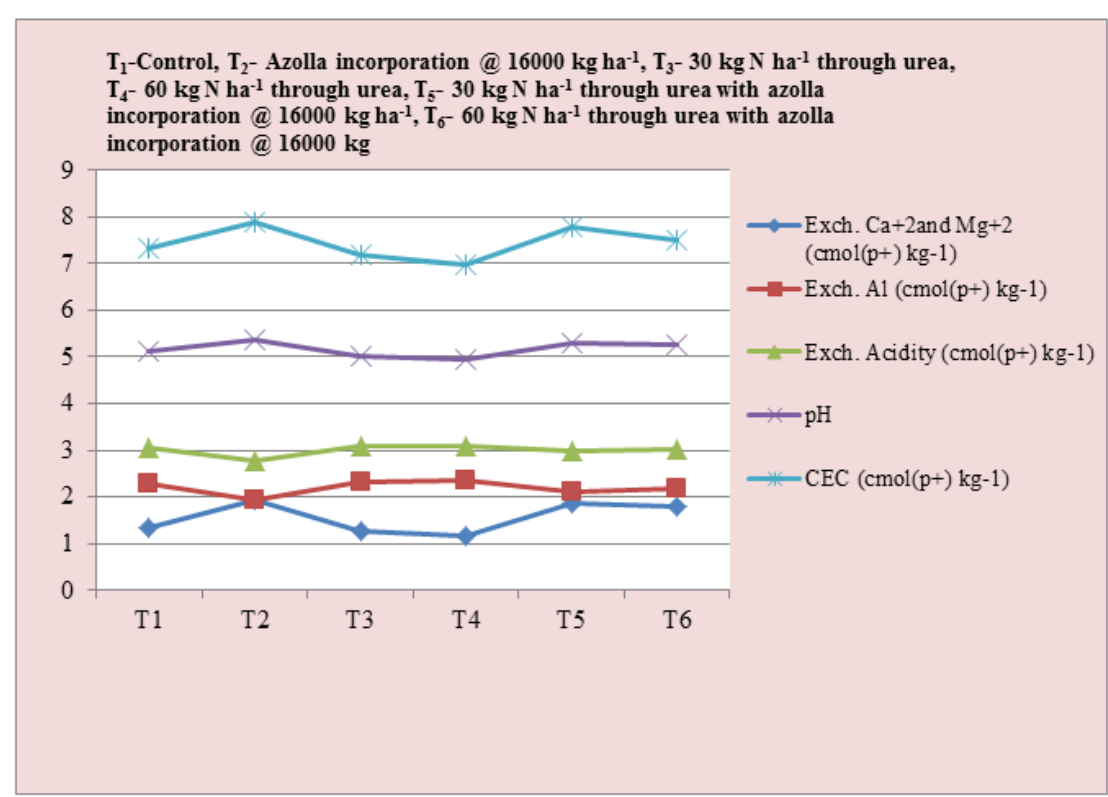

Fig-3: Soil acidity indices as afftected by azolla bio-fertilizer and urea after Rice harvesting in low land acidic soil of Meghalaya

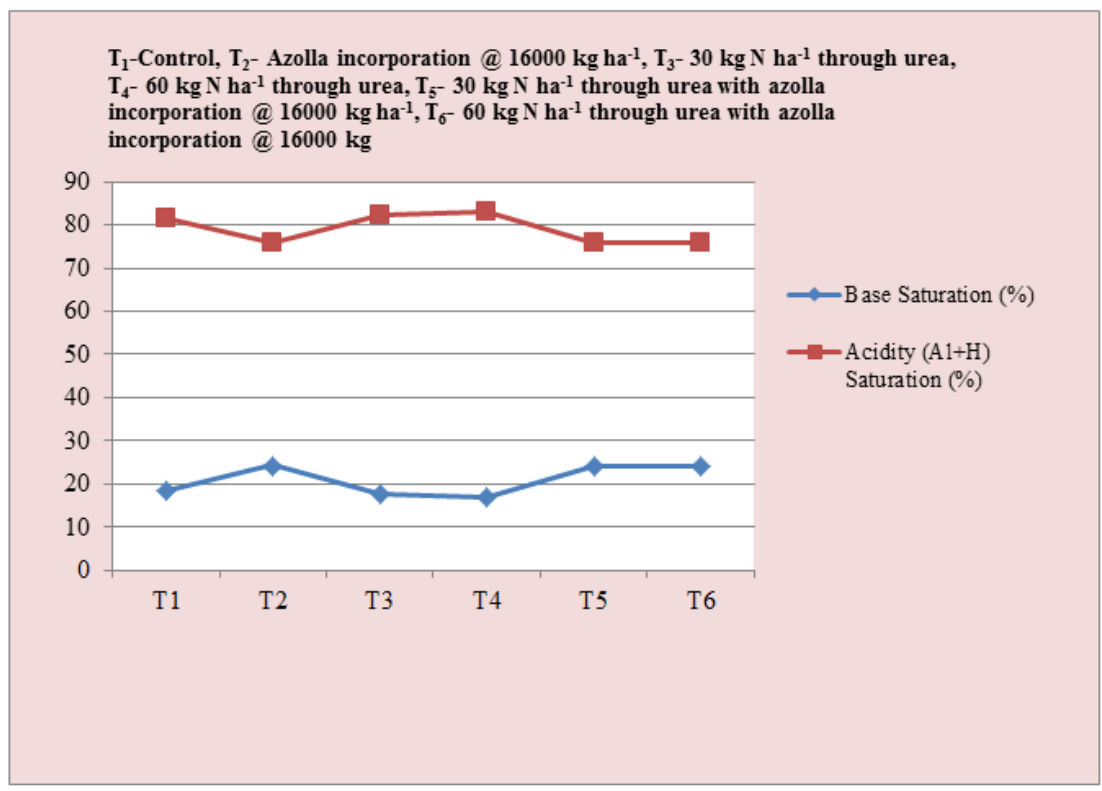

Fig-4: Soil acidity (Al+H) and base saturation (\%) as afftected by integrated Use of urea and azolla for rice cultivation in low land acidic soil of Meghalaya

\section{ACKNOWLEDGEMENTS}

The laboratory facility provided by School of Natural Resource Management, College of Post Graduate Studies in Agricultural Sciences, Central Agricultural University, Umiam (Barapani) for carrying out soil analysis for present study is duly acknowledged.

\section{REFERENCES}

1. Sumner, M.E. and Noble, A.D. (2003). Soil acidification: The world story. In: Handbook of Soil Acidity (ed. Rengel, Z.), Marcel Dekker, New York, 1-28.

2. Uexkull, H.V. and Mutert, E. (1995). Global extent, development and economic impact of acid soils. Plant Soil, 171, 1-15.

3. Narro, L., Pandey, S., Leon, C.D., Salazar, F. and Arias, M.P. (2001). Implication of soil-acidity tolerant maize cultivars to increase production in developing countries. In: Plant Nutrient Acquisition: New Perspectives (eds. Ae, N., Arihara, J., Okada, K. and Srinivasan, A.) Springer, Tokyo, 447-463. 
4. Mandal, S.C. (1997). Introduction and historical overview. In: Acidic Soils of India (eds. Mahapatra, I.C., Mandal, S.C., Misra, C., Mitra, G.N. and Panda, N.), ICAR, New Delhi, 3-24.

5. Sharma, U.C. and Singh, R.P. (2002). Acid soils of India: Their distribution, management and future strategies for higher productivity. Fertilizer News, 47(3), 45-52.

6. Pagani, A. and Mallarino, A.P. (2012). Comparison of methods to determine crop lime requirements under field conditions. Soil. Sci. Soc. Am. J, 76, 1855-1866.

7. Patiram (1991). Liming of acid soils and crop production in Sikkim. J. Hill Res, 4, 6-12.

8. Manoj-Kumar, Khan, M.H., Singh, P., Ngachan, S.V., Rajkhowa, D.J., Kumar, A. and Devi, M.H. (2012). Variable lime requirement based on differences in organic matter content of iso-acidic soils. Indian J. Hill Farm, 25(1), 26-30.

9. Oh, N.H. and Richter, D.D. (2004). Soil acidification induced by elevated atmospheric $\mathrm{CO}_{2}$. Global Change Biol, , 10, $1936-1946$.

10. Fageria, N.K. (2008). Optimum soil acidity indices for dry bean production on an oxisol in no-tillage system. Commun. Soil. Sci. Plant Anal, 39, 845-857.

11. Ohno, T., Fernandez, I.J., Hiradate, S. and Sherman, J.F. (2007). Effects of soil acidification and forest type on water soluble soil organic matter properties. Geoderma, 140, 176-187.

12. Ohno, T. and Amirbahma, A. (2010). Phosphorus availability in boreal forest soils: A geochemical and nutrient uptake modeling approach. Geoderma, 155, 46-54.

13. Bray R.H. and Kurtz, L.T. (1945). Determination of total, organic and available forms of phosphorus in soils. Soil Sci., 59(1), 3946.

14. Page, A.L., Miller, R.L. and Keeny, D.R. (1982). Chemical and microbiological properties. In: Methods of Soil Analysis, Part 2 (ed. Jackson, M.L.), 2nd Edition, Madison, Wisconsin, 39-594.

15. Gomez, K.A. and Gomez, A.A. (1984). Statistical Procedures for Agricultural Research. $2^{\text {nd }}$ edn. John Wiley and Sons, New York, 324.

16. Buragohain, S., Sarma, B., Nath, D.J., Gogoi, N., Meena, R.S. and Lal, R. (2018). Effect of 10 years of bio-fertilizers use on soil quality and rice yield on an Inceptisol in Assam, India. Soil Res, 56, 49-58.

17. Mensah, B.Y., Vlek, P.L.G., Manske, G. and Mensah, M. (2015). The influence of Azolla pinnata on floodwater chemistry, grain yield and nitrogen uptake of rice in Dano, South Western Burkina Faso. J. Agric. Sci. 7(8), 118-130.

18. Chandel, G., Banerjee, S., See, S., Meena, R., Sharma, D.J. and Verulkar, S.B. (2010). Effects of different nitrogen fertilizer levels and native soil properties on rice grain, Fe, Zn and protein contents. Rice Sci, 17(3), 213-227.

19. Ghosh, M., Mandal, B.K., Mandal, B.B., Lodh, S.B., and Dash, A.S. (2004). The effect of planting date and nitrogen management on yield and quality of aromatic rice (Oryza sativa). J. Agric. Sci., 142, 183-191.

20. Ladha, J.K., Dawe, D., Ventura, T.S., Singh, U., Ventura, W. and Watanabe, I. (2000). Long-term effects of urea and green manure on rice yields and nitrogen balance. Soil Sci. Soc. Am. J., 64, 1993-2001.

21. Mondal, S.S., Prasenjit, J., Chandra, K., and Pradyut, V. (2008). Integrated nutrient management for sustaining productivity and soil fertility build-up in rice-lathyrus-sesame cropping system. Indian J. Agric. Sci., 78, 534-536.

22. Mahdi, S.S., Hassan, G.I., Samoon, S.A., Rather, H.A., Showkat, A.D., and Zehra, B. (2010). Bio-fertilizers in organic agriculture. J. Phyto, 2(10), 42-54.

23. Bhuvaneshwari, K. and Singh, P.K. (2015). Response of nitrogen-fixing water fern Azolla bio-fertilization to rice crop. Biotech, 5(4), 523-529.

24. Zhang, H., Wang, B. and Xu, M. (2008). Effects of inorganic fertilizer inputs on grain yields and soil properties in a long-term wheat-corn cropping system in south China. Commun. Soil Sci. Plant Anal, 39, 1583-1599.

25. Yaduvanshi, N.P.S. and Sharma D.R. (2016). Utilization of organics, amendment and fertilizers with sodic water irrigation: Longterm effect on soil properties and rice-wheat productivity. J. Indian Soc. Soil Sci, 64(3), 255-260.

26. Hati, K.M., Swarup, A., Mishra, B., Manna, M.C., Wanjari, R.H., Mandal, K.G. and Misra, A.K. (2008). Impact of long-term application of fertilizer, manure and lime under intensive cropping on physical properties and organic carbon content of an Alfisol. Geoderma, 148, 173-179.

27. Sharma, S.B., Sayyed, R.Z., Trivedi, M.H., and Gobi, T.A. (2013). Phosphate solubilizing microbes: Sustainable approach for managing phosphorus deficiency in agricultural soils. Springer Plus, 2, 587.

28. Sohlihya, B. (2015). Influence of organic amendments on phosphorus nutrition and aluminium toxicity in groundnut. M.Sc. Thesis submitted to School of Natural Resource Management, College of Post Graduate Studies, CAU, Umiam, Meghalaya, 78.

29. Chyamweshi, R.A., Mukashema, A., Ruganzu, V., Gatarayiha, M.C., Nabahungu, N.L. and Mbonigaba, J.J. (2013). Improving nutrient availability and coffee yield on acid soils of the Central Plateau of Southern Rwanda. Afric. Crop Sci. Conf. Proc., 11, 803-810.

30. Sharma, S.B., Sayyed, R.Z., Trivedi, M.H., and Gobi, T.A. (2013). Phosphate solubilizing microbes: Sustainable approach for managing phosphorus deficiency in agricultural soils. Springer Plus, 2, 587.

31. Sohlihya, B. (2015). Influence of organic amendments on phosphorus nutrition and aluminium toxicity in groundnut. M.Sc. Thesis submitted to School of Natural Resource Management, College of Post Graduate Studies, CAU, Umiam, Meghalaya, 78.

32. Hati, K.M., Swarup, A., Mishra, B., Manna, M.C., Wanjari, R.H., Mandal, K.G. and Misra, A.K. (2008). Impact of long-term application of fertilizer, manure and lime under intensive cropping on physical properties and organic carbon content of an Alfisol. Geoderma, 148, 173-179. 